\title{
About My Soul and My Song-- Interpretation of the Cultural Genes and National Characteristics of Contemporary Fiber Art Works
}

\author{
Ling CHEN
}

College of Humanities and Social Sciences North China Electric Power University, Beijing, China

nnn101011@163.com

Keywords: handicraft, craft, wisdom, creativity

\begin{abstract}
The paper selects two craftspeople coming from different countries, studies their art works and tries to find the home of human spirits and wisdom from these artists who have deep understand of craft. The paper appeals to adopt the new viewpoint of old craft and study the raw state and create the future of human with wise.
\end{abstract}

\section{Introduction}

Craft is undoubtedly the oldest and most intelligent is the longest one of the production process. In addition to the arts and crafts of the material and the life of the fun, but also from the cultural characteristics of the human body. Remember once there was a Mexico artist said: I was in my own meaning to weave these baskets. Which has my song, and it also made into my soul. If I do a lot, I won't have my soul, nor my song. Then every basket is the same...... In today's rapid development of information society, twenty-first Century has just entered the human face of their homes, suddenly feeling and introspection, we see many social problems at the same time, also want to explore the true state of human, for the wisdom of our ancestors in ancient memory.

\section{A Person Who Comes From Norway with A Finger To Record Times}

Norway fiber artist Anne Stanbul's works, "all the beginning of the beginning," the reference Figure 3 pure and color, in the big ups and downs of the hills, the implication of the philosophical thinking about the. She and Nancy compared more like a romantic poet, see the world change constantly in subtle color. This piece of work by Norway traditional weaving techniques, bold composition xilian. And Nancy works the same is that the two of them are focusing on the subtle changes in color, delicate change, looking for a kind of difficult to express the beauty of good works are the focus of the implication, Italy not exposed.

Norway's fiber art, after the two World War, to obtain an unprecedented development, especially since 1970s, the textile process has been developed in Norway as a new art form, has become an important part of Norway modern technology. Common types of fiber art bonded wool and handmade paper, in addition to materials with different carving patterns and strong visual effect of textile printing fabric, and classical style tapestries and fashion etc... Norway famous art and art furniture as we know it is a good reputation as "a poet" of the "loom poet" Freda, Hansen Hana Reagan, Sinnova Anker Alda, etc., which fully proved the important position in the field of fiber art, Norway. In Norway today, "tapestry" has become a symbol, dating back to the past, women in fiber art is very influential. Today's artists and other artists can display their works in the large art galleries.

Anne's intent is not to show the things of the present state, but to show the beginning or end of everything. In the chaos, with the bright and pure lines and the dark side of the contrast, in the moment of their collision, the dark side of the night in the dark. As she said that:

"In the past and the future, this sudden and unexpected moment due to their current intensity and brightness become more real, more important, more precious. There is no memory at this moment, not expected, but with the feeling of this unconscious, separated from the time. Several seconds and minutes are different...... Every step I have become soft, I am very sensitive to this moment, try to seize the energy, as the aesthetic experience stored in my body, painting down to record, let it mature. 
Later, when the design drawing tapestry, I in the process of adding other aspects of thinking, surprise, sincerity, hope and love. Put all these note to the unborn tapestry, become a part of its life." When the artist talks about his own creative experience, he is talking about it. Anne went on to say, "first I work very naturally, painting, and then gradually to represent the essence of the factors that I want to tell the color and lines. In order to get the shadow color my special, I personally because of spinning, weaving, tapestry made more vivid, this is an extra bonus."

Anne all the time in the spinning and weaving. Thinking on the loom before, she is an enthusiastic optimistic weaver, hours a year to repeat doing the same thing. Her feelings and fingertips shuttle between the warp and weft, looking at the image gradually showing. Anne is engaged in the slow process, and she likes to do the thing in her own time. Anne said, "as a natural force is recorded by an inch of wool. Every day I think to see all my thoughts and feelings, are here -- my tapestry!" Anne to feel the feelings of life with all her all to a woman's heart, she hopes, "I hope is beyond time and space, keep all of my feelings, no frills model contains the whole world."

Norway is located in the Arctic, surrounded on three sides by the state, the winding coastline, numerous fjords, lofty mountains and steep hills rolling land. Norway winter long sunshine, sunshine time is short, the climate is cold and perennial snow, the plant species is relatively scarce. In this environment, the people of Norway formed a self-sufficient natural economy shape and unsociable, talkative, like interpersonal communication, more with nature "company" of the national character and habits. Although today's Norway because of the discovery of the Beihai oil field has entered the ranks of the economically developed countries, but the Norway people still maintain a lot of deep-rooted traditional habits. For example, many rich people in Norway to build a wooden house in the deep mountains and forests, house poor facilities, not even tap water and electric lights, televisions and other products of modern life. They hope to use the holidays "to recover the original simplicity" like life. According to statistics, more than $90 \%$ of the Norway people love outdoor activities, to alpine skiing, swim in the sea, go to the beach sunbathing is Norway "never" hobby. Many Norway people's mentality is that everyone from the front of the door to sweep the snow, the other people on the frost, their life habits are not people". Living in Norway, often see the people of Norway ", a powerful and unconstrained style, completely independent" a person walking in effect, in the field of jogging, basking in the sun on the lawn, three people, a group of five people to help get together to chat in Norway is extremely rare. Even between friends, parents and children are very few exchanges. "You go your way, I go mine

Anne's dedication and seriously to her in the field of fiber art to display their talents in the field of power and strength

In my opinion, the three artists from different countries, although the performance of the theme and content are different, but they are using the same weaving techniques, appreciate the wisdom and creativity of their ancestors in this ancient craft, along with the development of the industrial age, information age, people ignore this for people paying close attention to, lose this piece of land, although the development of science and technology has brought material wealth and comfort, people's creativity is limited, people experience in manual labor in the struggle and effort and success, feelings of joy, unity in the machinery operation lost.

If you follow the "checklist" your paper will conform to the requirements of the publisher and facilitate a problem-free publication process.

\section{A Great Man from France to Show the Basic Philosophy of the Olympic Games}

Jean Gerald was born in Paris in October 30, 1946. His early works are always repeat the same process: first, after making an expression of the idea of small size model in a random way, he will create a whole big in manufacturing drawings, drawings, he considers the weaving process constraints, but also allows the weaver can explain his works on the premise don't deviate from the original intention of the. The Weaver is not only a follow the prescribed order workers, but also an artistic creation of participants. Whether the performance of abstract or figurative content, his tapestry always shows a prudent and strict technology, without any artificial. 
As a contemporary as artists, he tended to grand theme, although very exquisite details of the tapestry can also cause his interest. This allows him to both show intimacy and joy of the scene, but also the performance of the sacred scene.

For many years, Lausanne, the Olympic capital, is also the center of the world's fiber arts. Various fields of art pilgrims must remember "Fiber Art Biennale", it attracted the fiber art from the world lovers, not far from their Wanshui to switzerland. As the artist was inspired by the Olympic spirit and ideal, Gallagher de decided to devote himself to the creation of the sport. The Museum of art named Gallagher De to complete the creation of the 17 pieces of monumental tapestries "for the ideal". One piece is 267 square meters, by more than 50 weavers in twelve workshops took a year to complete, this is aubusson had one of the largest.

"For the ideal" the creation process is this: Gerald put myself in the documents of the multitude, he spent long time thinking about the Olympic spirit of thought. This includes a variety of themes, such as the Olympic motto, athletes, winter and summer games and the wide range of the Olympic movement. No more than what can express the basic philosophy of tapestry of the Olympic. This kind of art is collective wisdom crystallization, he collected from various parts of the world and the Weaver's hand, and it uses materials -- wool, this is the world's most natural living materials. This masterpiece made an indelible impression in our hearts. This tapestry form can let the people of the world, by making people all over the world the most acceptable language, picture, color and has a variety of symbolic media to convey the Olympic spirit and information.

Tapestry just like an Olympic athlete, ready to be volunteers together to. "For the ideal" this masterpiece, the sublimation of Coubertin put forward the modern Olympic ideal. This picture of the fusion of ancient tapestry art and contemporary fabric of modern epic works to promote the spirit of the Olympic Games in the Olympic venues, will be appreciated by people all over the world.

\section{One Communicator from the United States to Seek Ancient Wisdom}

Nancy Kozkowski, shows us how an artist can accomplish the responsibility of the information society in the present time -- to seek and represent the true wisdom of human culture.

I can't imagine a than Nancy himself tells the story is better able to explain the: "when I was in when I was in high school, I encountered a Navajo woman (the largest American Indian tribes) at a car station. She sat beside the window of the Khans weaving things. I asked her if she could teach me to weave, so she promised to teach me. She taught me with spindle spinning, a small businessman walked over and said she should not teach white girls do this, so she stopped. Although she did not teach me, but at least I learned to spin. A frame Navajo weaving machine in a nearby hotel, I where according to machine drawn the whole loom: every line of it, each node and each line hammer, every I all don't pass. I don't know why every place is like that, but I think they must have their reasons. So I went home and built my own loom......" Nancy from the beginning with the Indian culture the indissoluble bound.

In the study, she was thinking, like many masters, think of yourself. She decided to find a place where she wanted to go, a direction of her own creation and a way to get there, and we all knew she would be successful. In a 'life, as the main focus of life weaving and. But some things are lost, after all, to the arts, to lose a lot of things than ordinary people. Nancy surprise found knitting experience in Mai Dannaou everyone. They take her back to their home, from under the bed struggled out of the blanket, said: "look, this is my mother knitting," other people have similar goods.

Nancy Kozkowski completely understands the history of weaving, and it is easy to enter the field of design. However, an image in her works has become the dominant, which is: stripes (see Figure 1).

In her works, the stripes can be expressed in other things. Like a flag, a belt, a ten or a letter. Although they are all stripes, but rich in change, she gave the stripes of different images and life. However, the pattern is unpredictable. These patterns are so beautiful, and not because of the shape of a strip and is simple, just the opposite. They look so rich and subtle. You can from the experience of many you never see the pattern, freedom, smart and full of the magnificent colors, which contains a deep Indian culture. 
Fabric is a silent language, in the process of weaving, weaving into their emotions. In the face of Nancy's fabric works, you can feel: This is not a personal sense of beauty, this is a generation of national aesthetic information retention and communication. Handuokelafu in the handicraft industry is on the verge of crisis at the end of the 19th century, before the hand looms creaked, listening to the fabric to tell people grief, although manual production lagged behind production machinery, time-consuming and laborious, but a warm hand but permanently in fabric. It is this kind of profound understanding of hand weaving, to explore its connotation lies: weaving bearing the specific culture and human wisdom. Nancy is the culture and the wisdom of the communicator.

Thoreau who is Writer shows the true meaning of life in "Walden" middle way: accept and live a full life rather than excessive consumption, will enable us to return to the homeland of mankind, and return to the ancient family, society, good work and leisure life order; to skills, creativity and create respect; return to a leisurely enough to make our daily rhythm to watch the sunrise and sunset and walk at the edge of the water; return to the society in which the life worth living; return to the breeding of several generations of memory places. In the innovation environment, slowly experience ancient human wisdom and skills will be our happiness, on the traditional skills of understanding will bring us a new enlightenment.

\section{References}

[1] Lin Le Cheng, the "contemporary international fiber art", Beijing: China Building Industry Press, 2004.

[2] Eaton Johannes. "Color art", Shanghai: Shanghai people's fine arts publishing house, 2004.

[3] Art for the wall, furniture \& accessories 14, (1999)New York: Kraus Sikes Inc.

[4] Dawn Trilling The, Language of Ornament. London: Thames and Hudson Press, 2001

[5] Fiber arts. America: Altamont Press, 2003

[6] The thread of new Mexico. America: (2001) Douglas Kent Hall and the Albuquerque Museum. 